16 Gardner MJ, Snee MP, Hall AJ, Powell CA, Downes S, Terrell JD. Results of case-control study of leukaemia and lymphoma among young people near Sellafield nuclear plant in West Cumbria. BMF 1990;300:423-9.

17 Gardner MJ. Paternal occupations of children with leukaemia. BMJ 1992;305: 715.

18 Beral V. Leukaemia and nuclear installations. $B M 7$ 1990;300:411-2.

19 McLaughlin JR, Anderson TW, Clarke EA, King W. Occupational exposure of fathers to ionizing radiation and the risk of leukaemia in offspring- a case-control study. Ottawa, Canada: Atomic Energy Control Board, 1992. (AECB project study. Ottawa,

20 Yoshimoto Y, Mabuchi K. Mortality and cancer risk among the offspring ( $\mathrm{Fi}$ ) of atomic bomb survivors. $\Im$ Radiat Res 1991;Suppl:294-300.

21 Urquhart JD, Black RJ, Muirhead MJ, Sharp L, Maxwell M, Eden OB, et al. Case-control study of leukaemia and non-Hodgkin's lymphoma in childre in Caithness near the Dounreay nuclear installation. BMJ 1991;302:687-92.

22 Doll R. The epidemiology of childhood leukaemia. Journal of Royal Statistical Society 1989;152:1-11.

23 Narod SA, Stiller C, Lenoir GM. An estimate of the heritable fraction of childhood cancer. Br f Cancer 1991;63:993-9.

24 Van Steensel-Mol HA, Valkenbuirg HA, Vandenbroucke JP, Van Zanen GE. Are maternal fertility problems related to childhood leukaemia? Int Epidemiol 1985:14:555-9.

25 Kaye SA, Robison LL, Smithson WA, Gunderson P, King FL, Neglia JP. Maternal reproductive history and birth characteristics in childhood acute leukaemia. Cancer 1991;68:1351-5.

26 Greaves MF. Speculations on the cause of childhood acute lymphoblastic leukaemia. Leukaemia 1988;2:120-5.

(Accepted l February 1993)

\section{Comparison of nifedipine and propranolol as second line agent for hypertension in black Kenyans}

\author{
N R Poulter, J E Sanderson, A V Thompson, * \\ P S Sever, C L Chang
}

Wellcome Trust Research Laboratories, PO Box 43640, Nairobi, Kenya N R Poulter, study coordinator

JE Sanderson, Wellcome lecturer in medicine A V Thompson, research associate

P S Sever, professor of clinical pharmacology and therapeutics C L Chang, research fellow

Correspondence to: Dr N R Poulter, Department of

Epidemiology and Public Health, University College London, London WC1E 6EA.

${ }^{\star}$ Dr Thompson has since died.

$B M 71993 ; 306: 621-2$
Nifedipine is reported to be particularly effective as an antihypertensive agent in low renin hypertension.' Because of the predominance of low renin hypertension among black Kenyan patients we compared the efficacy of propranolol plus diuretic, a standard treatment in Africa, ${ }^{2}$ with nifedipine plus diuretic in Kenyan patients whose blood pressure was not controlled by diuretic treatment.

\section{Patients, methods, and results}

Thirty seven black Kenyans aged 30-69 attending a hospital clinic for hypertension were admitted to this double blind crossover trial. All treatment was withdrawn for a minimum of two weeks, after which inclusion in the trial depended on a diastolic blood pressure $>105 \mathrm{~mm} \mathrm{Hg}$. This was followed by four weeks of treatment with a diuretic (hydrochlorothiazide $25 \mathrm{mg}$ once daily), when those whose diastolic blood pressure fell below $90 \mathrm{~mm} \mathrm{Hg}$ were withdrawn from the trial. Patients were then randomly allocated, in balanced blocks of four, to six weeks' treatment with either diuretic plus slow release nifedipine $20 \mathrm{mg}$ twice daily or diuretic plus propranolol $80 \mathrm{mg}$ twice daily. After another four weeks of treatment with diuretic alone the study treatments were crossed over.

Blood pressure was measured with a random zero sphygmomanometer by one of three observers whose technique had been standardised beforehand. At each visit blood pressure was recorded twice after five minutes' lying down, a radial pulse being measured between readings, and blood pressure and radial pulse were recorded after two minutes' standing. Patients were seen every two weeks throughout the trial. At the start of the trial and at the end of each stage patients were weighed and full biochemical blood screens, including plasma renin activity, were carried out. Plasma renin activity was estimated (after standardised sampling) by radioimmunoassay of angiotensin I generated by incubating plasma for four hours. Results were analysed with Student's $t$ test for paired data and Hills and Armitage's method for analysing data from crossover trials.

Five patients were withdrawn after responding to diuretic treatment alone. Another patient withdrew because of work commitments, and two were withdrawn while taking propranolol (one patient's diastolic blood pressure rose above $125 \mathrm{~mm} \mathrm{Hg}$ and one had symptoms suggesting heart failure). Of the 29 remaining patients, 16 initially took nifedipine plus diuretic. This combination produced significantly lower systolic and diastolic blood pressures than propranolol plus diuretic $(p<0.05)$ (table). Both combinations of drugs significantly reduced blood pressure compared with diuretic alone $(p<0.05)$.

There were no significant changes in the patients' mean weight and serum creatinine and sodium concentrations throughout the trial. Serum uric acid and blood urea concentrations rose and serum potassium fell significantly during diuretic treatment, suggesting good compliance (confirmed by pill counts and the changes in pulse rates). Plasma renin activity was low and changed with treatment (table). Twenty two patients' lying mean arterial blood pressure and 19 patients' standing mean arterial blood pressure fell more with nifedipine than with propranolol. Although those whose blood pressure fell more when nifedipine was added to diuretic had a lower mean plasma renin activity $(0.47(\mathrm{SD} 0.60) \mathrm{nmol} / / \mathrm{h})$, these differences were not significant ( $t$ test). One patient was withdrawn because of side effects (see above), but, otherwise, side effects were few. No patients complained of severe headaches or flushing while taking nifedipine.

\section{Comment}

Both diuretics and calcium antagonists are effective and superior to $\beta$ blockers in treating black hypertensive patients. ${ }^{4}$ We have previously shown diuretics plus nifedipine to be an effective combination for black

Mean (95\% confidence interval) lying and standing blood pressure and pulse rate and median (range) plasma renin activity in 29 patients at each stage of trial

\begin{tabular}{|c|c|c|c|c|c|c|c|}
\hline & \multicolumn{3}{|c|}{ Lying } & \multicolumn{3}{|c|}{ Standing } & \multirow{3}{*}{$\begin{array}{c}\text { Plasma } \\
\text { renin } \\
\text { activity } \\
(\mathrm{nmol} / \mathrm{h})\end{array}$} \\
\hline & \multicolumn{2}{|c|}{ Blood pressure ( $\mathrm{mm} \mathrm{Hg}$ ) } & \multirow{2}{*}{$\begin{array}{l}\text { Pulse rate } \\
\text { (beats } / \mathrm{min} \text { ) }\end{array}$} & \multicolumn{2}{|c|}{ Blood pressure $(\mathrm{mm} \mathrm{Hg})$} & \multirow{2}{*}{$\begin{array}{l}\text { Pulse rate } \\
\text { (beats/min) }\end{array}$} & \\
\hline & Systolic & Diastolic & & Systolic & Diastolic & & \\
\hline 1 Before treatment & $\begin{array}{c}180 \\
(169 \text { to } 191)\end{array}$ & $\begin{array}{c}114 \\
\text { (109 to } 119)\end{array}$ & $\begin{array}{c}70 \\
(66 \text { to } 74)\end{array}$ & $\begin{array}{c}175 \\
\text { (165 to } 184)\end{array}$ & $\begin{array}{c}122 \\
(116 \text { to } 127)\end{array}$ & $\begin{array}{c}79 \\
(74 \text { to } 83)\end{array}$ & $\begin{array}{c}0.02 \\
(0-1 \cdot 48)\end{array}$ \\
\hline 2 After diuretic alone & $\begin{array}{c}167 \\
\text { (156 to } 178)\end{array}$ & $\begin{array}{c}106 \\
\text { (101 to } 110)\end{array}$ & $\begin{array}{c}73 \\
\text { (69 to } 77)\end{array}$ & $\begin{array}{c}163 \\
\text { (154 to } 173 \text { ) }\end{array}$ & $\begin{array}{c}112 \\
\text { (107 to } 117 \text { ) }\end{array}$ & $\begin{array}{c}83 \\
\text { (78 to } 88)\end{array}$ & $\begin{array}{c}0.29 \\
(0-2 \cdot 65)\end{array}$ \\
\hline 3 After diuretic + propranolol & $\begin{array}{c}150 \\
\text { (140 to } 159)\end{array}$ & $\begin{array}{c}95 \\
\text { (91 to } 99 \text { ) }\end{array}$ & $\begin{array}{c}61 \\
\text { (57 to } 65)\end{array}$ & $\begin{array}{c}145 \\
\text { (135 to } 156)\end{array}$ & $\begin{array}{c}100 \\
\text { (96 to } 104)\end{array}$ & $\begin{array}{c}66 \\
\text { (61 to } 70)\end{array}$ & $\begin{array}{c}0 \cdot 23 \\
(0-6 \cdot 15)\end{array}$ \\
\hline 4 After diuretic + nifedipine & $\begin{array}{c}141 \\
(135 \text { to } 147)\end{array}$ & $\begin{array}{c}91 \\
(87 \text { to } 95)\end{array}$ & $\begin{array}{c}77 \\
\text { (72 to } 82)\end{array}$ & $\begin{array}{c}135 \\
\text { (129 to } 141)\end{array}$ & $\begin{array}{c}94 \\
(89 \text { to } 99)\end{array}$ & $\begin{array}{c}90 \\
\text { (84 to } 95)\end{array}$ & $\begin{array}{c}0.58 \\
(0-76 \cdot 9)\end{array}$ \\
\hline $\begin{array}{l}5 \text { Difference between } 3 \text { and } 4 \\
\text { averaged over periods }\end{array}$ & $\begin{array}{c}8 \cdot 2^{\star} \\
(0 \cdot 6 \text { to } 15 \cdot 8)\end{array}$ & $\begin{array}{c}4 \cdot 1^{\star} \\
(0 \cdot 2 \text { to } 8 \cdot 0)\end{array}$ & $\begin{array}{c}-15 \cdot 9 \star \star \\
(-20 \cdot 4 \text { to }-11 \cdot 4)\end{array}$ & $\begin{array}{c}9 \cdot 9^{\star} \\
(0.5 \text { to } 19 \cdot 3)\end{array}$ & $\begin{array}{c}6 \cdot 0^{\star} \\
(0.3 \text { to } 11 \cdot 7)\end{array}$ & $\begin{array}{c}24 \cdot 6 \star \star \star \\
(18 \cdot 7 \text { to } 30 \cdot 5)\end{array}$ & $0.66 t$ \\
\hline
\end{tabular}

${ }^{\star} \mathrm{p}<0.05,{ }^{\star \star} \mathrm{p}<0.01,{ }^{\star \star \star} \mathrm{p}<0.001$ ( $\mathrm{z}$ test). ${ }^{3} \quad \mathrm{tp}<0.01$ for difference between medians (Mann-Whitney rank sum test). 
hypertensive patients. ${ }^{5}$ In this study nifedipine plus diuretic lowered blood pressure more effectively than propranolol plus diuretic, which has previously been shown to be effective in black hypertensive patients. ${ }^{2}$ Although comparisons of fixed doses of drugs have limitations, the doses of propranolol and nifedipine used were in the middle of their therapeutic ranges. Experience in Kenyan hypertension clinics confirms reports that black hypertensive patients have lower plasma renin activities than white patients. Perhaps because of this, we found nifedipine plus diuretic to be an excellent combination for treating hypertension among black Kenyan patients.

This study was sponsored by the Wellcome Trust. We thank Dr M Hills for his advice regarding analyses.

1 Erne P, Bolli P, Bertel O, Hulthen L, Kiowski W, Muller FB, et al. Factor influencing the hypotensive effects of calcium antagonists. Hypertension 1983;5(suppl 11):S97-102.

2 Seedat YK. Trial of atenolol and chlorthalidone for hypertension in black South Africans. $B M Y$ 1980;281:1241-3.

3 Hills M, Armitage P. The two-period cross-over clinical trial. Br $\mathrm{f}$ Clin Pharmacol 1979;8:7-20.

4 Zing W, Ferguson RK, Vlasses PH. Calcium antagonists in elderly and hypertensive patients. Arch Intern Med 1991;151:2154-62.

5 Poulter NR, Thompson AV, Sever PS. Do diuretics enhance the hypotensive effect of nifedipine? A double blind crossover trial. $₹$ Hypertens 1986;4:792-3.

(Accepted 21 September 1992)

\section{Cancer mortality and atenolol treatment}

Medicine, Royal

Postgraduate Medical

School, Hammersmith

Hospital, London

W12 0NN

A E Fletcher, senior lecturer

in epidemiology

C J Bulpitt, professor of

geriatric medicine

C T Dollery, dean

A J Palmer, research officer

Department of Medicine,

Dudley Road Hospital, Birmingham B18 7QH

D G Beevers, reader in

medicine

Department of Computing and Medical Statistics,

University of Wales

College of Medicine,

Cardiff CF4 4XN

E C Coles, senior lecturer

Department of Medicine

John Radcliffe Hospital,

Oxford OX3 9DU

J G Ledingham, professor of

medicine

Clinical Pharmacology

Unit, Department of

Medicine and

Therapeutics, University

of Aberdeen, Aberdeen

AB9 1FX

$\mathrm{J}$ C Petrie, professor of clinical

pharmacology

J Webster, consultant

physician

BMF 1993;306:622-3

\section{A E Fletcher, D G Beevers, C J Bulpitt, E C Coles, C T Dollery, J G Ledingham, A J Palmer, J C Petrie, J Webster}

In the Medical Research Council's randomised trial of elderly hypertensive patients, men receiving atenolol had a higher death rate from cancer than those receiving diuretic or placebo. ${ }^{1}$ This was not observed in women receiving atenolol, whose mortality was similar to those receiving diuretic and lower than those receiving placebo. The extra cancer deaths were apparently from lung cancer. A randomised trial of elderly hypertensive patients in primary care reported a non-significant excess of fatal cancers of the bronchus in the group given atenolol compared with the control group (an excess risk of $1.89,95 \%$ confidence interval 0.88 to 4.08$).^{2}$ We therefore examined the relation between atenolol treatment and cancer in a large study of hypertensive patients.

\section{Methods and results}

The Department of Health hypertension care computing project is a longitudinal study of patients who attended one of five hospital hypertension clinics $(95 \%)$ or four general practices $(5 \%)$ in the United Kingdom during 1971-86, with continuing mortality follow up. ${ }^{34}$ Our analyses are based on deaths until 31 October 1990. Patients were placed in mutually exclusive groups according to type of antihypertensive treatment: any record of atenolol treatment irrespective of other concomitant treatments; any record of another $\beta$ blocker irrespective of other concomitant treatments except atenolol; any record of methyldopa treatment irrespective of concomitant treatments except any $\beta$ blocker; or any record of diuretic treatment irrespective of other concomitant treatments except any $\beta$ blocker or methyldopa.

Patient years of observation were measured from the first date of a prescription up to the patient's death or 31 October 1990. Mortalities from cancer (cancer given as the underlying cause of death) were calculated for each treatment and were adjusted for age by the direct method. We compared the risks between treatments with the Cox proportional hazards model, adjusting for age and smoking. We performed a nested case-control study of deaths from lung cancer, matching 79 cases (58 men and 21 women: 68 with lung cancer given as the underlying cause of death and 11 with any mention of lung cancer on the death certificate) with 154 controls. We also calculated standardised mortality ratios for all hypertensive patients.

There was no evidence for an adverse relation between atenolol and all cancers or lung cancer (table). Adjustment of the relative risks for smoking made little difference. Women taking atenolol appeared to be at lower risk of lung cancer, but the number of deaths was small and confidence intervals wide. There was no evidence that treatment had different effects on men and women. Blood pressure (whether treated or untreated, systolic or diastolic) showed no relation with deaths from all cancers or lung cancer.

A conditional multiple logistic regression analysis of our case-control study gave a relative risk from smoking of 4.2 (95\% confidence interval 1.9 to 9.0 , $\mathrm{p}<0.0004)$ and from atenolol treatment of $0.9(0.4$ to $2 \cdot 1, \mathrm{p}=0 \cdot 7)$. The only excess standardised mortality ratio was for renal cancer (ICD codes 1890-9) with a value of 196 (107 to $328, p=0.03$ ) for men and women combined.

\section{Comment}

We found no evidence to support previous suggestions of an excess of cancer in men treated with

Death rates adjusted for age and relative risks from cancer for different antihypertensive treatments

\begin{tabular}{|c|c|c|c|c|c|c|c|c|c|c|c|c|}
\hline \multirow[b]{3}{*}{ Treatment } & \multirow{3}{*}{$\begin{array}{l}\text { Mean (SD) } \\
\text { age }\end{array}$} & \multirow{3}{*}{$\begin{array}{c}\text { Patient } \\
\text { years of } \\
\text { observation }\end{array}$} & \multicolumn{2}{|c|}{ Deaths from all cancers } & \multicolumn{2}{|c|}{ Deaths from lung cancer } & \multicolumn{4}{|c|}{ Relative risk ( $95 \%$ confidence interval) compared to atenolol } & \multirow{2}{*}{\multicolumn{2}{|c|}{ All other treatments combined }} \\
\hline & & & & No/1000 & & No/1000 & \multirow{2}{*}{$\begin{array}{c}\text { All } \\
\text { cancers }\end{array}$} & \multirow{2}{*}{$\begin{array}{l}\text { All cancers } \\
\text { adjusted for } \\
\text { smoking }\end{array}$} & \multirow{2}{*}{$\begin{array}{l}\text { Lung } \\
\text { cancer }\end{array}$} & \multirow{2}{*}{$\begin{array}{l}\text { Lung cancer } \\
\text { adjusted for } \\
\text { smoking }\end{array}$} & & \\
\hline & & & Total & years & Total & years & & & & & All cancers & Lung cancer \\
\hline \multicolumn{13}{|c|}{ Men } \\
\hline Atenolol $(n=2313)$ & $52(11)$ & 17409 & 85 & $5 \cdot 6$ & 20 & $1 \cdot 3$ & 1.0 & $1 \cdot 0$ & 1.0 & $1 \cdot 0$ & & \\
\hline $\begin{array}{c}\text { Other } \beta \text { blockers } \\
(n=706)\end{array}$ & $52(11)$ & 8660 & 42 & $4 \cdot 6$ & 10 & $1 \cdot 3$ & $\begin{array}{c}0.8 \\
(0.5 \text { to } 1.2)\end{array}$ & $\begin{array}{c}0.8 \\
(0.5 \text { to } 1.2)\end{array}$ & $\begin{array}{c}1 \cdot 1 \\
(0.5 \text { to } 2 \cdot 3)\end{array}$ & $\begin{array}{c}1.1 \\
(0.5 \text { to } 2 \cdot 4)\end{array}$ & & \\
\hline Methyldopa $(n=316)$ & $57(11)$ & 3335 & 35 & $7 \cdot 3$ & 8 & $1 \cdot 7$ & $\begin{array}{c}1.5 \\
(1.0 \text { to } 2 \cdot 2)\end{array}$ & $\begin{array}{c}1.4 \\
(0.9 \text { to } 2 \cdot 2)\end{array}$ & $\begin{array}{c}1 \cdot 7 \\
(0 \cdot 7 \text { to } 4 \cdot 0)\end{array}$ & $\begin{array}{c}1.6 \\
(0.6 \text { to } 3.9)\end{array}$ & $\begin{array}{c}0.9 \\
(0.7 \text { to } 1.3)\end{array}$ & $\begin{array}{c}1 \cdot 2 \\
(0 \cdot 7 \text { to } 2 \cdot 3)\end{array}$ \\
\hline Diuretic $(n=570)$ & $54(12)$ & 5231 & 32 & $5 \cdot 5$ & 11 & 1.9 & $\begin{array}{c}1.0 \\
(0.7 \text { to } 1.5)\end{array}$ & $\begin{array}{c}1.0 \\
(0.6 \text { to } 1.5)\end{array}$ & $\begin{array}{c}1.5 \\
(0.7 \text { to } 3 \cdot 2)\end{array}$ & $\begin{array}{c}1.6 \\
(0.7 \text { to } 3.5)\end{array}$ & & \\
\hline \multicolumn{13}{|c|}{ Women } \\
\hline Atenolol ( $\mathrm{n}=2199$ ) & $53(13)$ & 17350 & 57 & $3 \cdot 7$ & 5 & 0.4 & \multirow{4}{*}{$\begin{array}{c}1.0 \\
1.0 \\
(0.7 \text { to } 1.6) \\
0.9 \\
(0.5 \text { to } 1.6) \\
0.9 \\
(0.6 \text { to } 1.4)\end{array}$} & $1 \cdot 0$ & 1.0 & 1.0 & \multirow{4}{*}{$\begin{array}{c}0.9 \\
(0.7 \text { to } 1.4)\end{array}$} & \multirow{4}{*}{$\begin{array}{c}2.5 \\
(0.8 \text { to } 7 \cdot 9)\end{array}$} \\
\hline $\begin{array}{l}\text { Other } \beta \text { blockers } \\
(n=797)\end{array}$ & $53(13)$ & 9420 & 42 & $4 \cdot 4$ & 6 & $0 \cdot 6$ & & $\begin{array}{c}1.0 \\
(0.6 \text { to } 1.6)\end{array}$ & $\begin{array}{c}2 \cdot 7 \\
(0 \cdot 8 \text { to } 9 \cdot 0)\end{array}$ & $\begin{array}{c}3.0 \\
(0.8 \text { to } 10.7)\end{array}$ & & \\
\hline Methyldopa $(n=383)$ & $57(13)$ & 4765 & 24 & $4 \cdot 1$ & 5 & 1.0 & & $\begin{array}{c}1.1 \\
(0.6 \text { to } 1.9)\end{array}$ & $\begin{array}{c}2.8 \\
(0.7 \text { to } 10.8)\end{array}$ & $\begin{array}{c}3.6 \\
(0.9 \text { to } 15.2)\end{array}$ & & \\
\hline Diuretic $(n=755)$ & $55(14)$ & 7286 & 27 & $3 \cdot 5$ & 4 & 0.6 & & $\begin{array}{c}0.8 \\
(0.5 \text { to } 1.3)\end{array}$ & $\begin{array}{c}1.4 \\
(0.4 \text { to } 5.5)\end{array}$ & $\begin{array}{c}1 \cdot 3 \\
(0 \cdot 3 \text { to } 6 \cdot 0)\end{array}$ & & \\
\hline
\end{tabular}

